\title{
EXAMINING THE IMPACT OF ACADEMIC DEVELOPMENT IN THE ENGINEERING FACULTIES IN CHILE. CHANGES IN TEACHING PHILOSOPHY AND TEACHERS' COMPETENCIES
}

\author{
Roxana Acosta Peña ${ }^{1}$ D, Marina Tomás-Folch ${ }^{2}$ iD Mònica Feixas $^{3}$ iD \\ ${ }^{1}$ Universidad Católica del Norte (Chile) and Doctoral Program in Education, Department of Applied \\ Pedagogy, Universitat Autònoma de Barcelona (Spain) \\ ${ }^{2}$ Universitat Autònoma de Barcelona (Spain) \\ ${ }^{3}$ Universitat Autònoma de Barcelona (Spain) and Zurich University of Teacher Education (Switzerland) \\ roxana.acostap@gmail.com, marina.tomas@uab.cat, monica.feixas@uab.cat
}

Received November 2016

Accepted March 2017

\section{Abstract}

The Faculties of Engineering Sciences at Universidad Católica del Norte in Chile regard teacher training as a necessary tool for its academics' professional development and as a fundamental way to improve their teaching quality. The Teaching Unit for Innovation in Engineering (UIDIN) has developed a new curriculum and training programme which seeks to support the faculty in its implementation. This article presents some of the outcomes of a study aimed at qualitatively examining the development of the faculty's conceptions and philosophy of teaching and improvements in pedagogical competencies as a result of the implementation and transfer of the training programme. The teaching philosophy is described in different ways, but overall it considers teaching an act of disciplinary knowledge transfer based on students' interests, skills and attitudes, and with a heavy emphasis on building students' core values. Interviews reveal changes in the participants' learning and competencies due to the training, along with a positive impact on the teachers' lesson planning assessment strategies, students' feedback and the willingness to engage in more reflexive teaching practice.

Keywords - Academic development, teaching philosophy, teaching competencies, impact, Engineering. 


\section{Introduction}

Numerous studies, most of them from English-speaking and European universities, have examined the issue of how to measure the impact of teacher training (Guskey, 2002; Gibbs \& Coffey, 2004; Postareff, Lindblom-Ylänne \& Nevgi, 2007; Hanbury, Prosser \& Rickinson, 2008; Stes, Min-Leliveld, Gijbels \& Van Petegem, 2010; Feixas, Duran, Fernández, Fernández, García San Pedro, Márquez et al., 2013). However, the lack of systematic evaluation is still a concern in Latin American universities. What teachers learn during their academic development programme is not clear (Fishman, Marx, Best, \& Tal, 2003), nor is the impact on the organisational and teaching cultures as a consequence of applying the new teaching competencies developed during training.

Assessment of training is a complex but a necessary task to detect the effects of training actions and to take decisions to optimise the quality of future training. There is a wide array of models to evaluate teacher training (Kirkpatrick, 1998; Guskey, 2002; Kreber \& Brook, 2001; Stes et al., 2010; Gairín, 2010; Biencinto \& Carballo, 2004; Parsons, Hill, Holland \& Willis, 2012; De Rijdt, Stes, Van der Vleuten \& Dochy., 2013; Feixas et al., 2013) yet there is no consensus on the optimal model. Thus, it largely depends on the research objectives and the available resources (Chalmers, 2012). However, they all propose evaluating at least the impacts on the participants, the students and the institution's teaching culture.

Many Chilean universities offer academic development programmes to their faculty who are just getting their start teaching, along with those who have been teaching at the university for a while. However, we know very little about the efficacy of these training programmes and the evaluation of their impact on improving the quality of teaching and the results of students' learning. The purpose of this article is to present some of the results of the qualitative phase of a broader study that evaluates the impact and transfer of teacher training in the Faculties of Engineering at the Universidad Católica del Norte on the universities campuses of the Region of Antofagasta and Coquimbo, Chile.

This article reports on the attainment of two main research objectives aimed at examining the changes in the teaching philosophy and competencies of university professors as a result of their participation in an academic development programme in Chile. 


\section{Teaching beliefs, practices and strategies}

In order to ensure teaching quality at universities and keep up with the challenges, teachers need to be trained effectively (Entwistle, 2009). Fundamental knowledge of teaching methods as well as basic teaching skills are essential elements of academic development at universities. However, teaching conceptions and philosophy as an attitudinal part of the teaching competency need to be addressed, even though they have been neglected in many European universities (Lehner, 2016; Åkerlind, 2008; Ginns, Kitay \& Prosser, 2008; Kember, 1997).

Conceptions are difficult to change because they are deeply rooted in teachers' beliefs. All teachers hold personal conceptions of and approaches to teaching which result from their experiences as students and teachers (Pratt, 1992; Ramsden, 2003; Samuelowicz \& Bain, 1992). Studies on teachers' approaches to teaching identify two qualitatively different categories of teaching conceptions: the 'learning-focused' approach, which views teaching as facilitating students' learning and learning as the construction of knowledge, versus the 'content-focused' approach, which views teaching as the transmission of knowledge and learning as absorption of the information transmitted (Kember \& Kwan, 2000; Prosser \& Trigwell, 1997). These conceptions manifest themselves through teacher behaviours such as motivational attitudes, teaching strategies, attention to and engagement with students and assessment practices. In her research, Feixas (2010) revealed that some teachers were clearly and systematically either learningor content-focused, but most teachers reported a hybrid approach to teaching. Most profiles consisted of combinations of aforementioned approaches which varied depending on the discipline, which was termed "dissonant profiles" by Postareff, Katajavuoria, Lindblom-Ylänne and Trigwell (2008).

Academic development programmes can lead to changed conceptions of teaching, and consequentially to changes in teaching practice and student approaches to learning over time (Ho, 2000). To enhance faculty members' learning processes, deep approaches to learning have to be considered in the design of teacher training. But faculty members who participate in long-term pedagogical training which challenges their conceptions of teaching demonstrate considerably more positive self-efficacy beliefs than those who take short courses which can leave them uncertain about their understanding of teaching and learning (Stes et al., 2010; Postareff et al., 2007; Feixas et al., 2013). According to Prosser \& Trigwell (1997), faculty development should not direct every teaching activity towards student-centeredness but rather lead to teachers being 
"able to explain what teaching meant to them, and what learning meant to them [... and to gather] a relational conception on teaching and learning" (p. 282).

\section{Academic development at the Faculties of Engineering at Universidad Católica del Norte (UCN)}

One of the fundamental political mandates of the Faculties of Engineering at Universidad Católica del Norte is to continuously improve engineers' professional development. Despite considerable incremental improvements in indicators related to teacher professionalism and innovation of teaching methods, which have led to improvements in students' outcomes in terms of retention and employability, there is a significant gap between expected and achieved results. Within this framework, an innovation project emerged involving a total of 3,669 students and 123 faculty members whose goal was to reinvent the curriculum of UCN engineering teachers by establishing a new curricular structure based on the CDIO (Conceive-Design-ImplementOperate) approach (UCN PMI Project, 1204) posited by Crawley, Malmqvist, Östlund, Brodeur and Edström (2014).

The 36-month academic development programme conducted in the Faculty of Engineering and Geological Sciences, the Faculty of Engineering and Construction, the Faculty of Science, and the School of Risk Prevention and Environment located on the UCN's campuses in Antofagasta and Coquimbo in 2013 is part of a wider institutional improvement plan (PMI) called "Reinventing UCN Engineering", which in turn is included within the UCN 1204 Performance Agreement in the area of curriculum harmonisation.

The Teaching Unit for Innovation in Engineering (UIDIN) is responsible for implementing the programme to strengthen the quality of the teaching and the learning process for engineering students. The teacher training programme is designed based on the "Dictionary of teaching competencies", a tool to diagnose participants' training needs. Content-wise, it addresses common core topics such as course planning, active methodologies, student assessment, coaching and the use of ICT to support teaching from a competency-based, reflective and practiceoriented perspective. Teachers enrol in single modules or training activities lasting 5 to 30 hours. Teaching modalities include theoretical-practical workshops, some of them with follow-up sessions, and a strong focus on transfer. 


\section{Research method}

To meet the objectives of the study, we worked with a mixed methodological approach (Johnson, Onwuegbuzie \& Turner, 2007) using both quantitative and qualitative instruments (Creswell, 2014). A detailed analysis of the results from the quantitative phase is reported in a different article (Acosta, Feixas \& Quesada-Pallarès, 2016). The qualitative phase was carried out by applying a variety of instruments: open-ended questions on the respondents' vision of university teaching, semi-structured interviews, classroom observations and a focus group, all at different phases of the study (Phase 1: pre-training, Phase 2: during training, Phase 3: post-training, Phase 4: one year after the training), as shown in Table 1. This article focuses on the results of the open-ended questions and the interviews. To ascertain the changes in teaching conceptions of the faculty participating in the training programme, the open-ended question on their vision of university teaching was asked at two points during the study: before the training and after the training (20 months later).This question was part of the ATI-R questionnaire (Approaches to Teaching Inventory-Revisited, by Trigwell \& Prosser, 2005), which was designed to evaluate the teaching approaches via two scales: Professor-Centred Transmission of Information (PCTI) and Student-Centred Conceptual Change (SCCC). The purpose of the open-ended question was also to allow us to triangulate the information obtained via the quantitative and qualitative instruments in order to examine the changes in teaching conceptions and approaches after the training in more depth. The semi-structured interview was applied to 10 instructors chosen (12 months after the training had started) and it lasted one hour. It was an in-depth interview which provided comprehensive evidence of the application of the learning acquired and of the instructors' changed conceptions and competencies. The interview consisted in 20 questions organized around the main teaching competencies: lesson planning (3 questions), management of learning (2 questions), evaluation (4 questions), teaching innovation (4 questions), interpersonal communication (5 questions) and teamwork (5 questions).

\begin{tabular}{|l|l|l|l|l|l|}
\hline Levels & Instruments & \multicolumn{3}{|l|}{ Phase when the instrument was applied } \\
\hline & & Phase 1 & Phase 2 & Phase 3 & Phase 4 \\
\hline \multirow{2}{*}{ Instructors' learning } & Open-ended question & $\mathrm{x}$ & & $\mathrm{x}$ & \\
\cline { 2 - 6 } & Semi-structured interview & & & $\mathrm{x}$ & \\
\hline Transfer & Classroom observation & & $\mathrm{x}$ & & $\mathrm{x}$ \\
\hline $\begin{array}{l}\text { Impact of the training on the } \\
\text { institution's teaching and } \\
\text { organisational culture }\end{array}$ & Focus group & & & & $\mathrm{x}$ \\
\hline
\end{tabular}

Table 1. Qualitative instruments 


\section{Sample}

A total of 66 instructors participating in the teacher training programme in the Faculties of Engineering at the UCN responded to the open-ended question on their vision of university instruction. In order to further delve into the development of the teaching competencies suggested after the training, we chose an intentional sample of 10 professors (Patton, 1990) and tracked them over time by applying qualitative instruments, namely a semi-structured interview and two classroom observations. For reasons of space, the systematic observations of all 10 instructors will not be reported in this article. The selection of the 10 case studies was governed by the following criteria: having participated in the teacher training programme, responded to all three questionnaires in the qualitative phase and provided their consent to participate in the qualitative phase of the study.

The profile of the 66 participants is as follows: most of the respondents are women $(71.2 \%)$; their average age is 52 (with 11 years of deviation, i.e., the majority of instructors were between 41 and 63 years old). With regard to disciplines, 80.3\% are from Engineering, 16.7\% from Sciences and 3\% are from Psychology. Only 36.4\% of the instructors have had prior teacher training. Regarding their educational level, 9.2\% have a 4-year degree Bachelor's degree, $6.2 \%$ are Master's candidates, 40\% have a Master's degree, $4.6 \%$ are $\mathrm{PhD}$ candidates and $40 \%$ have doctorates.

The profile sample of the 10 teachers was intentionally selected (Table 2): 6 men and 4 women, average age 4-the majority were between 54 and 58 years old; 7 from Engineering and 3 from Sciences, 1 with a Bachelor's degree, 6 with Master's degrees and 3 with doctorates.

\begin{tabular}{|c|c|c|c|c|c|c|c|}
\hline Interviewee & Gender & Age & Profession & $\begin{array}{l}\text { Highest } \\
\text { academic } \\
\text { degree }\end{array}$ & Department & Discipline & $\begin{array}{c}\text { Years of } \\
\text { experience }\end{array}$ \\
\hline T3E-D8 & $\mathrm{F}$ & 55 & Civil engineer- IT & $\begin{array}{l}\text { Master's } \\
\text { degree }\end{array}$ & $\begin{array}{c}\text { Computer } \\
\text { Engineering and } \\
\text { Systems }\end{array}$ & Engineering & 30 \\
\hline T3E-D18 & $\mathrm{F}$ & 37 & $\begin{array}{l}\text { Civil engineer- } \\
\text { Metallurgy }\end{array}$ & Doctorate & $\begin{array}{c}\text { Metallurgical } \\
\text { Engineering and } \\
\text { Mining }\end{array}$ & Engineering & 3 \\
\hline T3E-D25 & $\mathrm{F}$ & 55 & $\begin{array}{l}\text { Professor in Chemistry } \\
\text { and Natural Sciences }\end{array}$ & $\begin{array}{l}\text { Master's } \\
\text { degree }\end{array}$ & $\begin{array}{l}\text { Basic science } \\
\text { teaching }\end{array}$ & Basic Sciences & 5 \\
\hline T3E-D41 & M & 58 & $\begin{array}{l}\text { Civil- industrial } \\
\text { engineer }\end{array}$ & $\begin{array}{l}\text { Bachelor's } \\
\text { degree }\end{array}$ & $\begin{array}{l}\text { Industrial } \\
\text { engineer }\end{array}$ & Engineering & 4 \\
\hline T3E-D57 & $\mathrm{F}$ & 47 & Physics & $\begin{array}{l}\text { Master's } \\
\text { degree }\end{array}$ & Physics & Basic Sciences & 10 \\
\hline
\end{tabular}




\begin{tabular}{|c|c|c|c|c|c|c|c|}
\hline Interviewee & Gender & Age & Profession & $\begin{array}{c}\text { Highest } \\
\text { academic } \\
\text { degree }\end{array}$ & Department & Discipline & $\begin{array}{c}\text { Years of } \\
\text { experience }\end{array}$ \\
\hline T3E-D56 & $\mathrm{M}$ & 39 & Civil engineer & Doctorate & Civil Engineering & Engineering & 11 \\
\hline T3E-D67 & $\mathrm{M}$ & 28 & $\begin{array}{c}\text { Engineer in Risk } \\
\text { Prevention and } \\
\text { Environment }\end{array}$ & $\begin{array}{c}\text { Master's } \\
\text { degree }\end{array}$ & $\begin{array}{c}\text { Engineering in } \\
\text { Risk Prevention } \\
\text { and Environment }\end{array}$ & Engineering & 5 \\
\hline T3E-D75 & $\mathrm{M}$ & 55 & Construction Engineer & Doctorate & $\begin{array}{c}\text { Construction } \\
\text { Engineer }\end{array}$ & Engineering & 17 \\
\hline T3E-D80 & $\mathrm{M}$ & 39 & $\begin{array}{c}\text { Engineer in } \\
\text { Computation and IT }\end{array}$ & $\begin{array}{c}\text { Master's } \\
\text { degree }\end{array}$ & $\begin{array}{c}\text { Comgineering and } \\
\text { Systems }\end{array}$ & Engineering & 13 \\
\hline T3E-D86 & $\mathrm{M}$ & 65 & $\begin{array}{c}\text { Professor in Chemistry } \\
\text { and Sciences }\end{array}$ & $\begin{array}{c}\text { Master's } \\
\text { degree }\end{array}$ & $\begin{array}{c}\text { Basic science } \\
\text { teaching }\end{array}$ & Basic Sciences & 23 \\
\hline
\end{tabular}

Table 2. Detailed description of the 10 case studies

\section{Data analysis}

The qualitative analysis allowed us to describe the experiences of the individuals studied from their own perspective, using their own language and their own expressions (Creswell, 2014). The responses to the open-ended question and the interviews were transcribed in their entirety. We used the content analysis technique for each of the transcribed texts (open-ended question and interviews) via the process of categorising the thematic content of the data, using the theoretical approaches on teaching conceptions and approaches as a reference (Dunkin, 1990; Dall'Alba, 1991; Ramsden, 1993; Kember \& Gow, 1994; Prat et al., 1998; Trigwell \& Prosser, 1999). The information was codified at an initial level in which we identified units of meaning in order to establish the categories. Later the codification consisted in interpreting the meaning of the categories and making conceptual comparisons between them, leading to more general and inclusive categories (Creswell, 2014).

To process the data from the qualitative analysis, we used the programme MAXQDA 12. At first, we carried out the previous categorisation and later this categorisation was enriched with the categories that emerged. 


\section{Results and discussion}

\subsection{Changes in participants' teaching philosophy based on the open-ended question on their vision of university instruction}

The analysis of the responses shows evidence of nuances in the way the respondents envision teaching and learning, students, contents, methodology, the purposes of teaching and personal and environmental factors that influence their conceptions before and after the training.

A large group of instructors views teaching as a professional activity that seeks to achieve student learning. "University instruction is a professional activity which consists of offering learning opportunities through a series of mechanisms" (T3P-D93). Likewise, the instructor is primarily viewed as a facilitator of learning and, to a lesser extent, as an implementer of methodological strategies and a transmitter of knowledge and experience, after the training. "The instructor is a facilitator of learning, not a transmitter of knowledge" (T3P-D49).

Another group of instructors views teaching as the construction and development of competencies, skills and attitudes, while a third group perceive it as a professional training discipline and as the transmission of knowledge. The visions of instruction which focus on facilitating student learning and transmitting knowledge are more frequent and increase after the training. "It corresponds to transferring knowledge and experience from the teacher to the student" (T3P-D79).

Before the training, the instructors viewed teaching as developing competencies and supplying disciplinary knowledge, with a combination of approaches to teaching which range from transmitting knowledge to facilitating learning. To a lesser extent, teaching is viewed as the use of different methodologies, such as active methodologies. This view of teaching was retained after the teaching. "To me, teaching in the university means equipping students with knowledge and competencies for their future professional careers" (T1P-D42).

Before the training, learning was primarily viewed as a process of constructing knowledge. This vision diminished after the training, giving way to the conception of learning primarily as a process of reflection and inquiry. "Teaching and reflecting, justifying a line of reasoning, interpreting results and responding to a specific problem" (T3P-D61).

After the training, the vision of the student as the centre of learning became more prevalent, as did the fact that their learning has to be constructed based on their own knowledge, followed by the idea of developing disciplinary competencies. In turn, the perception that students have gaps 
in their knowledge, skills and attitudes diminished. "(...) that the student can seek their own development, that the young person is at the core of teaching and the instructor is a facilitator" (T3P-D64).

There were major differences after the training in the instructors' vision of the contents to be taught, the methodology and the purposes of teaching. Regarding contents, they are viewed as related to the profession, theoretically and practically linked to essential knowledge (knowing, knowing how to do, and knowing how to be). The teaching methodology is viewed as a combination of methodological strategies: from lectures and motivational activities to practical and lab activities, including the particular use of active methodologies. The purposes of teaching, after the training, were viewed as preparation for work life with the purpose of contributing to the country's economic and social development, as reflected in the following expression: "It is a professional training process with the goal of serving society from their respective disciplines" (T3P-D27).

The factors that influence teaching, as perceived by the instructors before and after the training, can be divided into personal factors (vocation, time and being trained in teaching methodologies) and environmental factors (support from authorities, poor working conditions and a lack of resources). Environmental factors were the ones mentioned the most by the instructors.

"Given its importance, it is essential to know how to teach"(T3P-D88).

"The authorities should support instructors instead of blaming them for everything" (T3P-D59).

\subsection{Changes in participants' teaching competencies based on the interviews}

The results of the interviews were analysed according to the comments about the impact that the teachers experienced after their participation in the training, and more specifically in their application of what they learned and the changes in their teaching skills. There are mainly six teaching skills, as described in the university's "Dictionary of Teaching Competencies": course planning, management of learning processes, student assessment, innovation, interpersonal competencies, and teamwork.

Regarding course planning competencies, the instructors positively rate what they learned in relation to the course planning of the subjects. They highlight aspects such as better organisation and order and alignment of content with students' learning outcomes. However, they also admit that while prior to their participation in the training programme, they did not plan, now they do make course plans: 
"Before there was no planning, there were only a few warnings that told you that you weren't teaching to the syllabus, but the planning was the class syllabus, it wasn't lesson planning" (T3ED75).

The second competency developed is the management of learning processes. Teachers describe management of learning as an abstract process that takes shape in a very important teaching competency that goes beyond planning and instead implies projection and constant improvement in student learning:

"It means seeing objectives, what we are planning to do, materialising it, evaluating it and making any improvements needed, and then applying it again with these improvements" (T3E- D75)

With regard to assessment competencies, the instructors say that student feedback has allowed them to better know and improve their teaching process:

"The student feedback has been the most important aspect to develop... Previously, evaluation was equivalent to grading, giving a mark, but now it is more than that" (T3E- D8).

The incorporation of evaluation rubrics has allowed the student evaluation process to becomes systematized, consensus-based and transparent:

"The use of rubrics - that has been the main change. Before, I would come to class and give the students just the grade: "You got a 7.0, a 6.0 or 5.0", but today it's not like that anymore, it is more formal ... Before, the evaluation was a black box - it should not be like this" (T3E- D67).

Regarding teaching innovation competencies, the instructors stated their willingness to use different alternative methodologies and different teaching and technology resources. The instructors critically reflect during the process and on their results with the intention of improving their teaching performance and optimising student learning.

"But in my case I can do it and incorporate it, and if it doesn't work out or I don't feel comfortable, I change and adapt it... the instructor has to accept a certain level of risk" (T3E- D67). 
"In terms of innovation, the academic aspect is fundamental; you have to dare to try new things" (T3E- D86).

Regarding interpersonal communication competencies, teachers positively rate the contribution of the coaching strategy. They consider it very important for interpersonal communication:

"What has had the most impact on me was the coaching course. It has had a heavy impact... it has marked me, it has changed me ... My relationship with the students is somehow improving " (T3ED8).

Two teachers report personal and interpersonal changes in their relationship with students, with their increased concern for subjective and academic aspects.

"I try to establish relationships with students, to talk, to know a little more about them. Before, I didn't care, but now I take corrective actions on it and try to see what I can improve" (T3E-D80).

Finally, regarding teamwork competencies, the instructors expressed their satisfaction with sharing their interests with other instructors, collaborating actively and being committed to achieving shared goals. They perceive better teamwork and less of an individual focus, and they guide their students in the same direction.

"Being able to observe that my colleagues are also interested in making profound changes in their teaching and methodology and being pleased to see that we can do it all together" (T3E- D86).

The results obtained confirm the existence of different ways of expressing and representing university teaching:

Instruction is viewed in three ways: first, as a professional activity or discipline that seeks to achieve student learning, so teaching is viewed as a process of facilitating learning in which the instructor is a guide and facilitator of learning. The student is at the core of the learning process, and to learn they must construct their own knowledge via a process of reflection and 
inquiry. This vision is similar to what Ramsden (1993) calls theory 2: Teaching as the organisation of the student's activity, in which learning is viewed as a complex problem and teaching as a supervisory process which includes articulating techniques designed to ensure that the student learns. This vision is also related to the third level of Biggs and Moore (1993): to facilitate learning, and to the third level of Akerlind's hierarchy of inclusivity (2007): the outcomes of student learning, in terms of improving the student's learning and development.

A second way is related to viewing instruction as the construction and development of competencies, skills and attitudes, so teaching means developing competencies and supplying disciplinary knowledge. This vision is related to Ramsden's theory 3 (1993): teaching viewed as making learning possible.

Finally, in the third way instruction is perceived as the transmission of knowledge and experience, so teaching means the instructor providing disciplinary knowledge and sharing their own experience with the students. In Prosser and Trigwell's theory (1999), this would be Approach A: teacher-centred strategy with the intention of transmitting information to the students, or to Dall'Alba's second level (1991): teaching as transmitting information (from the instructor to the students).

\section{Conclusions}

With regard to learning teaching knowledge, skills, attitudes and competencies, we can conclude that the training programme offers interesting opportunities for academic development for the instructors in the Faculties of Engineering, primarily associated with two domains: one more instrumental or practical and the other more reflective or cultural.

The opportunities for instrumental or practical academic development stand out for the gradual development of the skills of planning and designing evaluation instruments and using teaching methods that are more student- and learning-centred, even when traditional teaching methods are used in combination with active learning strategies. The faculty members are more aware of the benefits of improving their performance as instructors and the quality of student learning. These results corroborate other results obtained in similar studies (Gibbs \& Coffey, 2004; Åkerlind, 2007; Postareff et al., 2007, 2008).

As part of the more cultural or reflective dimension, the training programme entailed a profound change in the way the challenges currently facing engineering professionals are dealt with, based 
on the CDIO model (Conceive-Design-Implement-Operate). In this sense, the instructors showed themselves to be more open to change and more flexible when assembling working teams with other instructors from their own department or faculty. They are also more capable of establishing more cordial, empathetic interpersonal communication with their students and view themselves as more willing to take risks; many of them now "dare to change" and innovate in their teaching practice.

There was a group of instructors who had already been undertaking methodological innovations and had thus shown less resistance to change and, in general, the overall willingness of the selected sample of instructors was positive. While acknowledging that there are still aspects that need improvement, they recognise that their initiatives and innovations in teaching, through applying what they learned in the training programme, have yielded them positive results with their students, as they show more interest and cooperation when working with their classmates. Finally, the instructors in the study also admit that they are now more aware and clear that in order to substantially improve teaching quality and thus their students' learning results, the changes must come from everyone involved, not only from the instructors. Participating in a teacher development course offered the engineering professors both challenges and opportunities to develop their teaching experience, since they are involved in an ongoing process to stretch beyond the boundaries of their own discipline and pedagogical field (Postareff \& Nevgi, 2015).

The limitations of this study include the fact that the sample of instructors is small, which means that the results cannot be extrapolated beyond the university context. However, for the purposes of the UCN training plan, the study provides a major contribution in offering a qualitative evaluation of the impact on the subject's own teaching conceptions and competencies, which is critical and valid in improving subsequent training design processes.

\section{Acknowledgments}

Doctoral Thesis. "Transferencia de la formación docente: estudio de su impacto, en los docentes de las Facultades de Ingeniería de la Universidad Católica del Norte (Chile)", Programme in Education, Universitat Autónoma de Barcelona. (2017). 


\section{References}

Acosta, R., Feixas, M., \& Quesada-Pallarès, C. (2016). From discourse to action. How Engineering university teachers in Chile develop professionally and transfer their learning into practice. Zeitschrift für Hochschulentwicklung, 11(5), 163-185. Retrieved October 6th, 2016, from: http://www.zfhe.at/index.php/zfhe/article/view/979 https://doi.org/10.3217/zfhe-11-05/10

Åkerlind, G.S. (2007). Constraints on academics' potential for developing as a teacher - Variation in meaning. Studies in Higher Education, 32, 21-37. https://doi.org/10.1080/03075070601099416

Åkerlind, G. (2008). A phenomenographic approach to developing academics' understanding of the nature of teaching and learning. Teaching in Higher Education, 13(6), 633-644. https://doi.org/10.1080/13562510802452350

Biencinto, C., \& Carballo, R. (2004). Revisión de modelos de evaluación del impacto de la formación en el ámbito sanitario: De lo general a lo específico. Revista Electrónica de Investigación y Evaluación Educativa. 10(2). http://goo.gl/7k8bFz.

Biggs, J.B., \& Moore, P.J. (1993). The process of learning. Sydney: Prentice Hall of Australia.

Chalmers, D. (2012). Identification and implementation of the indicators and measures of the impact on teaching preparation programs in higher education (TPP impact). Retrieved August 24th, 2016, from: http://www.catl.uwa.edu.au/projects/tpp

Crawley, E.F., Malmqvist, J., Östlund, S., Brodeur, D.R., \& Edström, K. (2014). Rethinking Engineering Education. Bern: Springer International Publishing Switzerland.

https://doi.org/10.1007/978-3-319-05561-9

Creswell, J.W. (2014). Research design: Qualitative, quantitative and mixed approaches (4th Ed.). Los Angeles, CA: Sage.

Dall'Alba, G. (1991). Foreshadowing conceptions of teaching. En B. Ross (Ed.). Teaching for effective learning: research and development in higher education, 13. Sydney: Higher Education Research and Development Society of Australasia.

De Rijdt, C., Stes, A., Van der Vleuten, C., \& Dochy, F. (2013). Influencing variables and moderators of transfer of learning to the workplace within the area of staff development in higher education: research review. Educational Research Review, 8, 48-74. 
Dunkin, M. (1990). The induction of academic staff to a university: process and product. Higher Education, 20, 47-66. https://doi.org/10.1007/BF00162204

Entwistle, N.J. (2009). Teaching for understanding at university: Deep approaches and distinctive ways of thinking. Universities into the 21st century. Basingstoke, Hampshire, New York: Palgrave Macmillan. https://doi.org/10.1007/978-1-137-09106-2

Feixas, M., Duran, M.M., Fernández, I., Fernández, A., García San Pedro, M.J., Márquez, M.D. et al (2013). ¿Cómo medir la transferencia de la formación en Educación Superior?: El Cuestionario de Factores de Transferencia. Revista de Docencia Universitaria. REDU, 11(3) 219-248.

Feixas, M. (2010). Enfoques y concepciones docentes en la universidad. Relieve, 16(2), 1-27. http://www.uv.es/RELIEVE/v16n2/RELIEVEv16n2 2.htm

Fishman, B., Marx, R., Best, S., \& Tal, R. (2003). Linking teacher and student learning to improve professional development in systemic reform. Teaching and Teacher Education, 1(6), 643 -658. https://doi.org/10.1016/S0742-051X(03)00059-3

Gairín, J. (2010). La evaluación del impacto en programas de formación. REICE [online], 8, 5. http://www.rinace.net/reice/numeros/arts/vol8num5/art1.pdf

Gibbs, G., \& Coffey, M. (2004). The impact of training of university teachers on their teaching skills, their approach to teaching and the approach to learning of their students. Active Learning in Higher Education, 5(1), 87-100. https://doi.org/10.1177/1469787404040463

Ginns, P., Kitay, J., \& Prosser, M. (2008). Developing conceptions of teaching and the scholarship of teaching through a Graduate Certificate in Higher Education. International Journal for Academic Development, 13(3), 175-185. https://doi.org/10.1080/13601440802242382

Guskey, T.R. (2002). Does It Make a Difference? Evaluating Professional Development. Educational Leadership, 59(6), 45-51.

Hanbury, A., Prosser, M., \& Rickinson, M. (2008). The differential impact of UK accredited teaching development programmes on academics' approaches to teaching. Studies in Higher Education, 33(4), 469-483. https://doi.org/10.1080/03075070802211844

Ho, A. (2000). A conceptual change approach to staff development: A model for programme design. International Journal for Academic Development, 5(1), 30-41. 
Johnson, R.B., Onwuegbuzie, A.J., \& Turner, L.A. (2007). Toward a definition of Mixed Methods research. Journal of Mixed Methods Research, 1(2), 112-133. https://doi.org/10.1177/1558689806298224

Kember, D., \& Gow, L. (1994). Orientations to teaching and their effect on the quality of student learning. Journal of Higher Education, 65, 58-73. https://doi.org/10.2307/2943877

Kember, D. (1997). A reconceptualisation of the research into university academics' conceptions of teaching. Learning and Instruction, 7(3), 255-275. https://doi.org/10.1016/S0959-4752(96)00028-X

Kember, D., \& Kwan, K. (2000). Lecturers' approaches to teaching and their relationship to conceptions of good teaching. Instructional Science, 28(5), 469-490.

https://doi.org/10.1023/A:1026569608656

Kirkpatrick D.L. (1998). Evaluating Training Programmes. The Four Levels. (2nd Ed.). San Francisco: Berrett-Koehler Publishers, Inc.

Kreber, C., \& Brook, P. (2001). Impact evaluation of educational development programmes. International Journal for Academic Development, 6(2), 96-108. https://doi.org/10.1080/13601440110090749

Lehner, M. (2016) Visualizing individual conceptual development paths in faculty development. Zeitschrift für Hochschulentwicklung, 11(5),125-143. Retrieved October 6th, 2016, from: http://www.zfhe.at/index.php/zfhe/article/view/963 https://doi.org/10.3217/zfhe-11-05/08

Parsons, D., Hill, I., Holland, J., \& Willis, D. (2012). Impact of teaching development programmes in higher education. Retrieved August 15th, 2016, from:

http://jisctechdis.ac.uk/assets/documents/research/HEA Impact Teaching Development Prog.pf

Patton, M.Q. (1990). Qualitative evaluation and research methods. (2nd Ed.). London: Sage Publications.

Pineda, P. (2000). Evaluación del impacto de la formación en las organizaciones, Educar, 27, 119133.

Postareff, L., Lindblom-Ylänne, S., \& Nevgi, A. (2007). The effect of pedagogical training on teaching in higher education. Teaching and Teacher Education, 23(5), 557-571.

https://doi.org/10.1016/j.tate.2006.11.013

Postareff, L., Katajavuoria, N., Lindblom-Ylänne, S., \& Trigwell, K. (2008).Consonance and dissonance in descriptions of teaching of university teachers. Studies in Higher Education, 33(1), 49-61. https://doi.org/10.1080/03075070701794809 
Postareff, L., \& Nevgi, A. (2015). Development paths of university teachers during a pedagogical development course. Educar, 51(1), 37-52. https://doi.org/10.5565/rev/educar.647

Pratt, D.D. (1992). Conceptions of teaching. Adult Education Quarterly, 42(4), 203-220.

Prosser, M., \& Trigwell, K. (1997). Using Phenomenography in the Design of Programs for Teachers in Higher Education. Higher Education Research \& Development, 16(1), 41-54.

https://doi.org/10.1080/0729436970160104

Prosser, M., \& Trigwell, K. (1999). Understanding Learning and Teaching. Buckingham: Society for Research into Higher Education and Open University Press.

Ramsden, P. (1993). Learning to teach in higher education. London: Routledge.

Ramsden, P. (2003). Learning to teach in higher education. (2nd ed.). London: Routledge.

Rust, C. (2000). Do initial training courses have an impact on university teaching? The evidence from two evaluative studies of one course. Innovations in Education and Teaching International, 37(3), 254-262. https://doi.org/10.1080/13558000050138498

Samuelowicz, K., \& Bain, J.D. (1992). Conceptions of teaching held by academic teachers. Higher Education, 24, 93-111. https://doi.org/10.1007/BF00138620

Stes, A., Min-Leliveld, M.J., Gijbels, D., \& Van Petegem, P. (2010). The impact of instructional development in higher education: A state-of-the-art of the research. Educational Research Review, 5(1), 25-49. https://doi.org/10.1016/j.edurev.2009.07.001

Trigwell, K., Prosser, M., \& Ginns, P. (2005). Phenomenographic Pedagogy and a Revised "Approaches to Teaching Inventory". Higher Education Research and Development, 24(4), 349-360. https://doi.org/10.1080/07294360500284730

Published by OmniaScience (www.omniascience.com) Journal of Technology and Science Education, 2017 (www.jotse.org)

\section{@)}

Article's contents are provided on an Attribution-Non Commercial 3.0 Creative commons license. Readers are allowed to copy, distribute and communicate article's contents, provided the author's and JOTSE journal's names are included. It must not be used for commercial purposes. To see the complete licence contents, please visit http://creativecommons.org/licenses/by-nc/3.0/es/ 